\title{
Land of Opportunity: Economic Mobility in the United States
}

Kartik Athreya and Jessie Romero

$\mathrm{T}$ he gap between people in the highest percentiles of earnings and wealth distributions and the rest of society has grown significantly during the past several decades, a fact that has led to considerable public discussion about the nature of opportunities available in the United States. Often overlooked in this debate, however, is the importance of economic mobility - the extent to which people are able to move up and down the income ladder - in determining what inequality implies for opportunity. If mobility is high, for example, the level of inequality at any point in time is not necessarily cause for concern, since it's possible that today's poor will be tomorrow's rich. The potential for such upward mobility is the foundation of the American dream that has lured generations of immigrants to the United States.

The dream endures today. Nearly half of Americans aged 18-29 believe they will become rich at some point in their lifetimes, according to a 2012 Gallup Poll. But the odds are against them: In 2010 (the most recent year for which the Internal Revenue Service has published data), only about 5 percent of U.S. households earned more than $\$ 150,000$ per year, and about 1 percent earned more than $\$ 350,000$ per year. (See Figure 1). Most of those people, moreover, were not born to poor parents - especially not in recent years.

Understanding economic mobility is essential to understanding how observed levels and patterns of economic inequality relate to the implicit promise of American life. But this is complicated. Mobility and

- The authors would like to thank Huberto Ennis, Arantxa Jarque, Marianna Kudlyak, Karl Rhodes, and Aaron Steelman for valuable discussions and insights. The views expressed are those of the authors and not necessarily those of the Fed- eral Reserve Bank of Richmond or the Federal Reserve System. 
Figure 1 Thresholds for Selected Income Percentiles

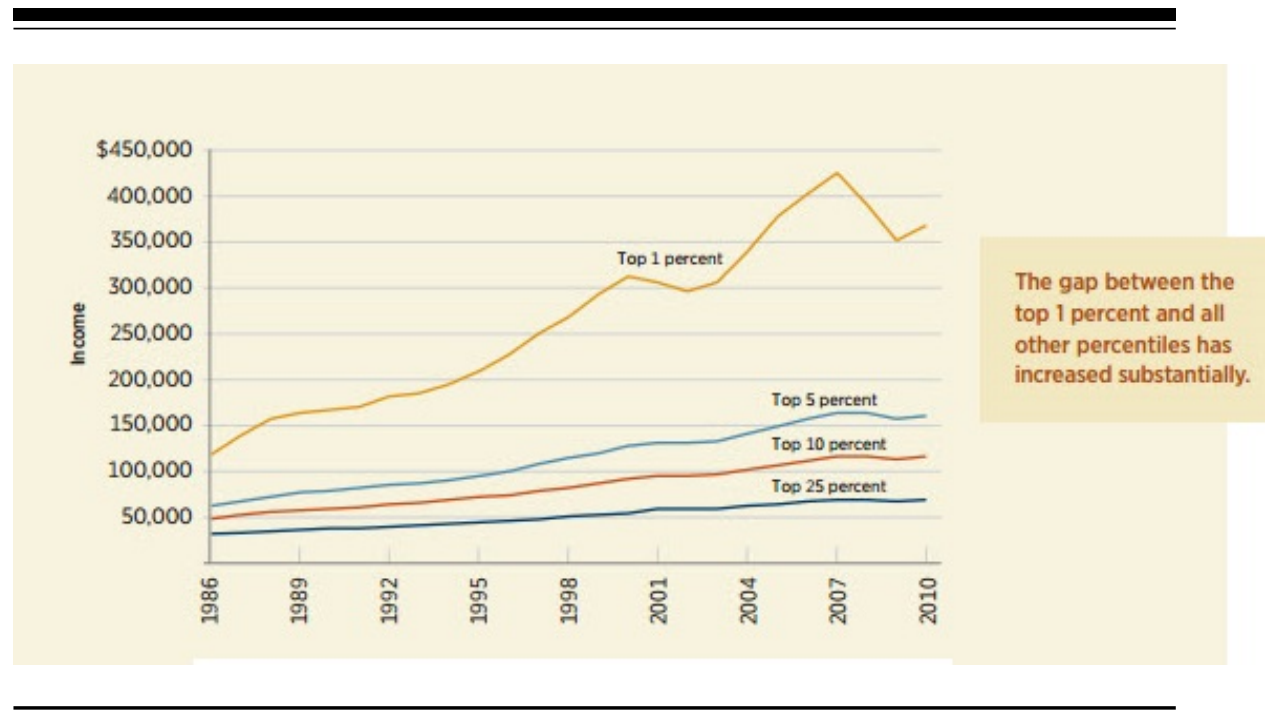

Source: Internal Revenue Service.

Notes: An "income percentile threshold" is the lowest amount earned by a household in that percentile. Income is "adjusted gross income," which is income minus certain deductions. Amounts are in current dollars.

inequality are determined jointly by random chance, by policy, andmost confounding of all for social scientists - by the deliberate actions of individuals or their parents. Regarding the latter determinant, it is clear that people differ according to their aptitude for various tasks, their appetite for risk, and their preferences for work versus leisure, among other characteristics. Both mobility and inequality thus will arise at least in part because different people make different choices. (See Appendix.)

This reality creates a challenge for economists seeking to understand the sources of observed levels of mobility and inequality, and for policymakers who hope to influence those levels. If everyone has the same opportunities for movement, then differences in income, wealth, or education must at least partially reflect deliberate choices and not market structure. This is not a setting in which many people would find efforts to alter outcomes via policy compelling. In contrast, to the extent that inequality continues across generations because people do not have the same chances, then inequality and immobility can be partially chalked up to market structure. From a normative standpoint, there 
thus might be support for policy interventions that seek to equalize opportunities, rather than those that would equalize outcomes.

One such intervention is greater investment in early education. High-quality early-childhood education equips children with the skills they need to succeed at each subsequent stage of life, yet in the United States, access to such education appears to strongly depend on parents' income. Children of poor parents are thus at a disadvantage from the very beginning - a disadvantage from which it is very difficult to recover. But these children are not the only ones who are affected; all else equal, a more skilled workforce increases the productivity of society as a whole. Enhancing early education opportunities for the initially disadvantaged could therefore lead to better economic outcomes for everyone.

This essay will review both recent and longer-run features of U.S. economic mobility, with a focus on how those trends affect the interpretation of data on income inequality. It then will discuss some of the challenges and choices facing policymakers seeking to alter observed outcomes.

\section{INEQUALITY IN THE UNITED STATES}

By nearly any measure, income inequality in the United States is increasing. ${ }^{1}$ In particular, today's rich are both richer than their counterparts in the past and richer relative to those around them. In 1979, the top 1 percent of households took home 7.4 percent of total aftertax income in the United States. By 2007, the share had more than doubled to 16.7 percent (Congressional Budget Office 2011). ${ }^{2}$ At the same time, the share of income earned by households at all levels of the remaining distribution stayed flat or declined. Those in the middle three quintiles (fifths), for example, saw their share decrease from 51 percent to 43.9 percent. The picture looks the same for pretax income; the share accruing to the top 1 percent rose from 8.9 percent to 18.7

\footnotetext{
${ }^{1}$ Economists also study consumption inequality, or differences in the amounts of goods and services that households purchase. Consumption inequality might differ from income inequality because of savings, taxes, or in-kind benefits such as food stamps. Some recent research suggests consumption inequality is much less pronounced than income inequality (e.g., Meyer and Sullivan [2013]), although other research finds that the trends in income and consumption inequality are very similar (e.g., Aguiar and Bils [2011]).

${ }^{2}$ The CBO defines after-tax income as market income (labor income, business income, capital gains, capital income, and other income) plus government transfers (such as Social Security payments, unemployment benefits, or in-kind transfers such as food stamps) minus taxes paid.
} 


\section{Figure 2 Income Distribution by Quintiles}

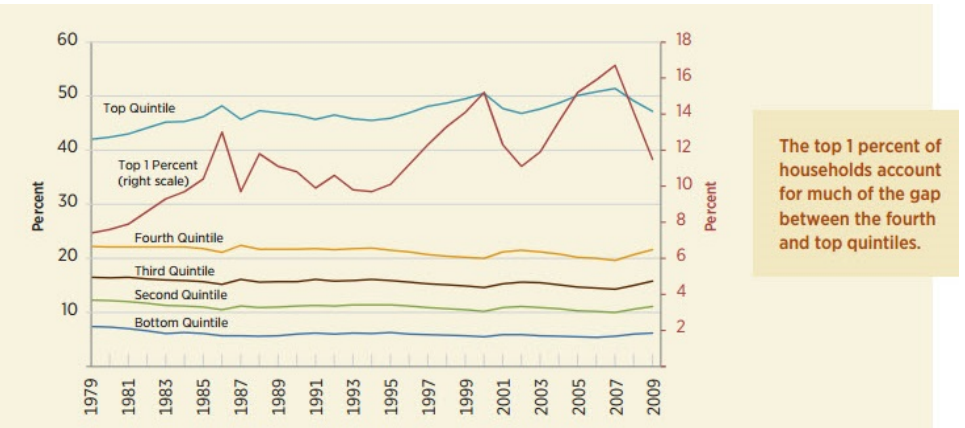

Source: Congressional Budget Office.

Notes: Quintiles are displayed on the left scale; the top 1 percent is displayed on the right scale. After-tax income is defined as market income (labor income, business income, capital gains, capital income, and other income) net of transfer payments and taxes.

percent (Congressional Budget Office 2011). ${ }^{3}$ These changes are a result both of increasing concentration of all types of income at the top of the distribution and a shift in the composition of income toward business income and capital gains (Congressional Budget Office 2011). This compositional change also makes incomes at the top of the distribution more volatile, but the trend is clearly one of growing inequality. (See Figure 2.)

Other research shows similar trends. Thomas Piketty and Emmanuel Saez (2003) find that after remaining flat throughout the 1950s and 1960s, the share of pretax income earned by the top 10 percent of households increased from 31.5 percent in 1970 to 41.4 percent in 1998. ${ }^{4}$ As in the CBO's analysis, this increase was largely driven by those at the very top of the distribution. While the income share for those in the 90th through 99th percentiles increased from 23.7 percent to 26.9 percent, the share for those in the very top percentile nearly doubled, from 7.8 percent to 14.6 percent..$^{5}$

\footnotetext{
${ }^{3}$ Data are from the supplemental data tables posted at www.cbo.gov/publication/43373.

${ }^{4}$ In Piketty and Saez (2003), the unit of analysis is a tax unit, defined as two married people living together (with or without dependents) or a single adult (with or without dependents). Their income measure excludes capital gains.

${ }^{5}$ Updated data are available at elsa.berkeley.edu/ ${ }^{\sim}$ saez/TabFig2011prel.xls.
} 
The trend continued after the 2007-09 recession. Although average real income for the top 1 percent fell about three times more than for the remaining 99 percent, the decline was almost entirely due to the stock market crash. As markets recovered in 2010, incomes for the top 1 percent increased 11.6 percent, compared to only 0.2 percent for all other households (Saez 2013).

Income shares for the 90th-99th percentiles and the top 1 percent continued to increase, to 29.1 percent and 17.4 percent, respectively, in 2011 (Piketty and Saez 2003, updated data).

These data have garnered a great deal of attention from economists, policymakers, and the public, but do they shed light on what is actually happening to individuals or households?

\section{MOBILITY: A CENTRAL FORCE BEHIND INEQUALITY}

An observation of inequality at any point in time is only a snapshot; it does not shed light on how that snapshot developed. For example, imagine three different worlds: In the first world, the first inhabitants flip coins to determine not only their income, but also the income of all future generations; each descendant earns either $\$ 1,000$ or $\$ 100,000$ per year, depending on his ancestor's original coin toss. In the second world, the members of each new generation flip coins, but they do so just once at birth to determine whether they will earn $\$ 1,000$ or $\$ 100,000$ per year during their lifetimes. In the third world, individuals get to flip a coin each year to determine their income for that year.

The people in these worlds face very different lifetime risks. The first world, which is akin to a caste system, is very risky from the perspective of the first ancestor, who is determining outcomes for an entire dynasty. The second world also is risky since the die is cast for one person's entire life, but each of her descendants gets a chance to flip the coin, making it unlikely that bad luck will persist across many generations. The third environment is the least risky since it is very unlikely that an individual's average annual income over his lifetime would be significantly different than $\$ 50,500$, the average annual income he can expect over many years.

Despite these differences, snapshots of these economies in any given year look the same. In each, about half the population earns $\$ 1,000$ per year, while the other half earns $\$ 100,000$. Clearly, then, inequality data alone do not reveal the underlying prospects of individuals. For this, one must study economic mobility. 


\section{TRENDS IN ECONOMIC MOBILITY}

Economists and policymakers generally are interested in two types of mobility: intragenerational and intergenerational. Intragenerational mobility describes how a given person's economic status changes over the course of his lifetime. Intergenerational mobility reflects the degree to which a person's economic status as an adult differs from that of her parents or ancestors. Status is usually measured by earnings (wage income), income (all sources of income, including wages), or less frequently wealth (the value of assets minus liabilities). Most research focuses on relative intra- and intergenerational mobility, or how a person's status changes in comparison to others. But it is also important to recognize that a person might experience absolute mobility even in the absence of relative mobility. She might occupy the same place in the earnings distribution as her parents, remaining in the same position relative to the rest of society, but still have a higher standard of living than her parents did, depending on the rate of economic growth. ${ }^{6}$

\section{Intragenerational Earnings Mobility}

Does the top of the income distribution comprise the same people year in and year out, or do individuals flow in and out of the highest percentiles over their lifetimes? If intragenerational mobility is high, then any snapshot of inequality will overstate the actual long-term inequality among individuals. For example, it is possible that the large gap in recent years between those in the top percentile and the rest of the distribution reflects an increase in the variation of annual earnings due to stock options and large bonuses. If that were the case, short-term inequality might be high, but long-term inequality could be much lower, reflecting high mobility.

In addition, in most modern societies, there is a clear life-cycle pattern to earnings and income. Imagine an extreme case where half the population earns $\$ 1,000$ during the first half of their lives and $\$ 100,000$ during the second half, while the other half of the population earns $\$ 100,000$ early in life and $\$ 1,000$ later. Income inequality would be high at a point in time, but everybody has the same lifetime income. Assuming that individuals could save and borrow to smooth their consumption over time, the snapshot of income inequality might not accurately reflect people's well-being since consumption inequality - a truer, and harder to measure, barometer - would be relatively low.

\footnotetext{
${ }^{6}$ For example, see Easterlin (2000).
} 
Anthony Shorrocks (1978) formalized these ideas by developing an index in which mobility is defined as the extent to which income inequality decreases over a given timeframe. Wojciech Kopczuk, Emmanuel Saez, and Jae Song (2010) calculate Shorrocks indices comparing inequality in annual earnings and in earnings averaged over five years for workers between 1937 and 2004. They find that short-term (five-year) mobility has not changed over the period, which implies that greater volatility of short-term earnings is not the source of observed higher inequality. Instead, higher inequality is likely the result of increased variation in lifetime earnings, including higher earnings at the top of the distribution. The authors conclude that mobility has not been sufficient to offset the rise in inequality, and thus that short-term inequality likely reflects lifetime inequality.

Kopczuk, Saez, and Song (2010) also find that long-term income mobility, from the beginning to the end of working life, actually increased significantly for all workers between 1942 and 1999. There is significant heterogeneity among groups of workers, however. Although on average men are more upwardly mobile than women, men's mobility was stable or declining during the sample period. Women's mobility, however, has increased greatly since the 1960s, as more women have moved into higher-paying professions. Thus, the increase in mobility for all workers has been driven by the labor market experiences of women.

Heterogeneity in intragenerational mobility also is apparent across the income distribution. Gerald Auten, Geoffrey Gee, and Nicholas Turner (2013) find that about 75 percent of taxpayers aged 35-40 who were in the second, third, or fourth quintile in 1987 were in a different quintile in 2007. (About 60 percent of those who changed position moved up or down a single quintile.) But they find greater persistence at the top and bottom of the distribution: 43 percent of taxpayers in the bottom quintile were still there 20 years later, and 46 percent of taxpayers in the top quintile maintained their positions. The authors also find that the very top earners tended to remain top earners: From 1992 through 2006, between 60 percent and 70 percent of the top 1 percent in a given year were in the top 1 percent in the following year.

\section{Intergenerational Mobility}

A commonly used measure of intergenerational mobility is the intergenerational elasticity of earnings (IGE). The IGE describes in percentage terms how much of the difference between the earnings of families in one generation persists into the next generation, typically by comparing the correlation of the earnings of fathers and sons. For example, an IGE of 0.5 means that a 10 percent difference between the income of 
two fathers translates into a 5 percent difference in the income of their sons. The smaller the IGE, the greater the amount of mobility.

Important early studies of the United States and other developed countries found a high degree of mobility, with an IGE of 0.2 or less (Becker and Tomes 1986). Later research, however, found that data used in this work featured biases that would lead to artificially low measurements of the true level of earnings persistence. (See Stokey [1996] for a review of this research.)

New and better data suggest that mobility in the United States has been historically lower than initial estimates implied, and that it has declined even further in recent decades. Daniel Aaronson and Bhashkar Mazumder (2008) construct a time series of intergenerational elasticity from 1950 to 2000. They find that mobility increased between 1950 and 1980 - the IGE decreased from 0.40 to 0.32 - but decreased significantly during the 1980 s and 1990s, with the IGE reaching 0.58 by 2000 .

Although exact international comparisons are not possible, most research suggests that people in the United States are somewhat less mobile than people in Canada, Denmark, Finland, and Norway, where the IGE is about 0.15 to 0.2 . In Germany and Switzerland, the IGE is about 0.3, and people in the United Kingdom and France also are relatively immobile, with IGEs of about 0.4 to 0.5 (Corak 2006).

While the IGE is a widely used statistic in work on intergenerational mobility, it only reflects average mobility across the entire distribution of individuals; it does not reveal anything about the direction of mobility or how it varies across different groups. To learn more about such mobility, Mazumder (2008) calculates transition rates, the likelihood of moving from one point in the distribution to another, across generations. He finds that, as with intragenerational measures, the amount of mobility varies significantly according to income. For example, there is a great deal of "stickiness" at the top and bottom of the distribution; people whose parents are in the bottom quintile of income are more likely to be in the bottom quintile themselves, and those whose parents are in the top quintile are likely to remain there. More than 60 percent of children whose parents are in the bottom quintile will end up in the bottom or second quintile, compared to 23.3 percent of those whose parents are in the top quintile. Only 7.4 percent of people who reach the top quintile are from families in the bottom quintile. (See Figure 3.) There also are stark differences between black people and white people and between men and women. Whites appear to be more upwardly mobile and less downwardly mobile than blacks. Mazumder (2008) finds that about 24.9 percent of whites remain in the bottom quintile, compared to 43.7 percent of blacks. And 38.9 percent of whites remain in the top quintile, compared to 21.3 percent of blacks. In addition, more 
Figure 3 Intergenerational Income Quintile Transition Rates

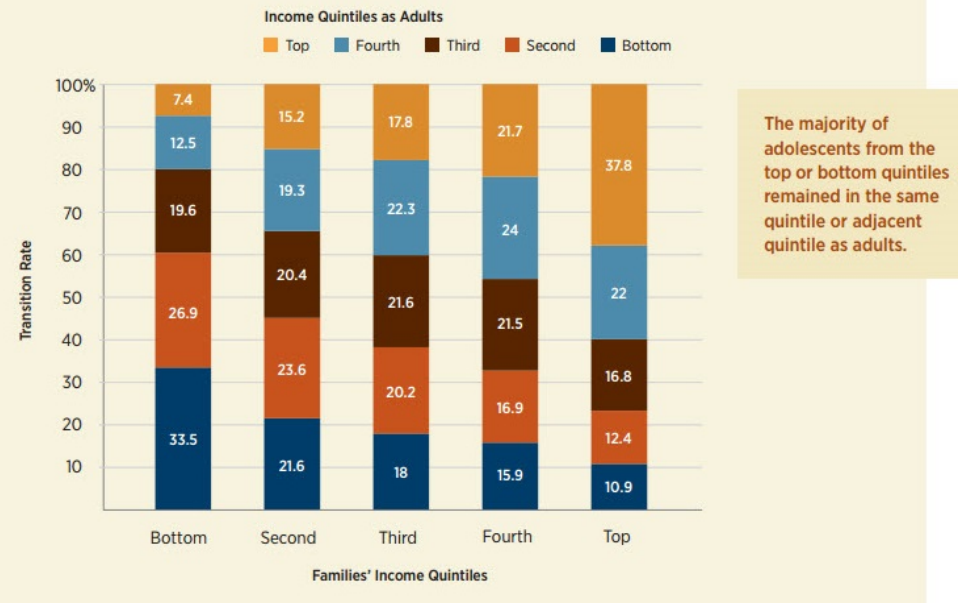

Source: Mazumder (2008).

Notes: The figure shows what percentages of adolescents from families in a given income quintile remained in that quintile or transitioned to a different quintile as adults. For example, 33.5 percent of adolescents from families in the bottom quintile remained in the bottom quintile, while 26.9 percent moved to the second quintile. Income data were gathered from 1979 through 1980 and again from 1997 through 2003.

than twice as many whites as blacks experience the "rags-to-riches" scenario of moving from the bottom quintile to the top quintile, 10.6 percent compared to 4.1 percent. Mazumder also finds a large gender gap. While 40.5 percent of women from families in the lowest quintile remain there, only 27.2 percent of men do. Conversely, 43.0 percent of men from families in the top quintile remain in that quintile, compared to 31.9 percent of women. Men are thus more upwardly mobile and less downwardly mobile than women. The gender gap is trumped by the race gap, however: Both black men and black women tend to be the most likely to remain in the bottom quintile and the most likely to fall out of the top quintile. ${ }^{7}$

\footnotetext{
${ }^{7}$ Isaacs (2008) finds similar differences in black and white mobility.
} 


\section{Mobility of Immigrants}

For centuries, the American dream has drawn immigrants to the United States, from the waves of German and Irish immigrants in the late 1800s to the nearly 12 million Mexican immigrants who arrived during the past four decades. ${ }^{8}$ But how likely is it that the dream becomes a reality?

Decennial census data indicate that immigrants' earnings increase rapidly after they arrive in the United States; the earnings gap between them and their native-born peers appears to shrink substantially over time. Comparing natives and immigrants with similar work experience, Darren Lubotsky (2007) finds that the positive earnings gap between natives and the cohort of immigrants who came to the United States between 1965 and 1969 fell from 38 percent in the 1970 Census to 16 percent in the 1980 Census, and vanished by the 1990 Census. The gap between natives and immigrants who arrived in the late 1980s fell from 55 percent to 36 percent between the 1990 and 2000 censuses. This mobility might be spurious, however. Up to one-third of immigrants eventually return to their home countries; if these immigrants tend to be those with lower earnings, then the apparent earnings growth actually reflects fewer low earners in the data pool. Lubotsky (2007) corrects for this "selective out-migration" by studying longitudinal rather than cross-sectional data, and finds that earnings growth is significantly lower. In the cross-sectional data, immigrants' relative earnings increase 20 percent during their first decade in the United States and an additional 10 percent to 20 percent in each following decade. In the longitudinal data, however, immigrants' earnings grow between 12 percent and 15 percent during their first 15 years in the country and then stagnate.

The mobility of the second generation also appears to be decreasing. Throughout the 20th century, the children of immigrants not only earned more than their parents, but they also earned more on average than the rest of the non-immigrant population, perhaps reflecting some of the selection effects Lubotsky (2007) observed. But that advantage is shrinking. In 1940, the second generation earned 17.8 percent more than non-immigrants on average. In 1970, the difference was 14.6 percent, and by 2000, the difference had fallen to 6.3 percent (Borjas 2006). The reason might be a shift in the composition of immigrants. There has long been significant heterogeneity in earnings among immigrant

\footnotetext{
${ }^{8}$ The number includes undocumented immigrants. Since the 2007-09 recession, net migration from Mexico has fallen to virtually zero. Between 2007 and 2011, the number of undocumented Mexican immigrants in the United States declined by about 1 million (Passel, Cohn, and Gonzalez-Barrera 2012).
} 
groups, and in recent times, immigrants from developed countries tend to earn more than those from developing countries. Immigrants from Germany earned 24.9 percent more than non-immigrants in 1970 and their children earned 19.5 percent more in 2000, for example, while those from Mexico earned 31.6 percent less in 1970 and their children earned 14.6 percent less in 2000 (Borjas 2006). ${ }^{9}$ While wages in the second generation tend to regress toward the mean, overall earnings show significant persistence into the second generation. Borjas (2006) finds that across all immigrant groups, the intergenerational elasticity over the period 1970 to 2000 is 0.43 . As the composition of immigrants increasingly shifts toward people from less-developed countries, who tend to have lower skills and levels of education, the wage gap is likely to persist through successive generations of immigrants (Haskins 2008). ${ }^{10}$ Irrespective of how quickly immigrants' earnings approach the earnings of natives, many immigrants still improve their economic status significantly by immigrating to the United States. In this sense, the move to the United States is a powerful form of economic mobility, and the United States' absorption of both legal and illegal immigrants makes it an engine of global mobility.

This last point must be part of any meaningful assessment of the mobility offered by a society. Even a calcified society, in which intergenerational or intragenerational mobility of natives is low, may be a source of mobility for the world's residents via its openness to immigrants. Conversely, societies that promote intergenerational mobility of natives through intensive early intervention and generous social safety nets but limit entry of immigrants - perhaps out of fear that they will exploit the generous safety nets - might hinder equality of opportunity in a global sense. ${ }^{11}$

\section{WHAT GENERATES PERSISTENCE?}

The preceding discussion has highlighted empirical findings on the persistence of economic outcomes both within and across generations. But these findings do not explain why persistence across generations

\footnotetext{
${ }^{9}$ Because the flow of immigrants from Mexico has been substantially greater than the flow from developed countries, the average wage of first-generation immigrants is still lower than the average wage of their native-born peers.

${ }^{10}$ Immigrant mobility matters not only for the prospects of the immigrants themselves, but also for measured inequality in society as a whole. Imagine a room in which everyone is six feet tall. If a group of shorter people enter the room, measured inequality in height will increase. In the context of immigration, the arrival of a group with wealth, skills, or education significantly different from those of natives can mechanically increase inequality at a point in time.

${ }^{11}$ See, for example, Pritchett (2006).
} 
exists in the first place or why it might have increased. As Aaronson and Mazumder (2008) note, intergenerational elasticities do not reflect causality. Instead, measures like the IGE are simply omnibus measures of everything correlated with parents' income and children's future earnings - factors ranging from the neighborhood where a child grew up to the availability of health care, among many others.

Intuitively, parents' decisions to invest in developing their children's skills, or "human capital," are important. Their willingness to make such investments stems in large part from altruistic concern for their children. ${ }^{12}$ One model that incorporates this dynamic was created by Gary Solon (2004). He relates this investment decision to the rate of return to human capital and to the progressivity of public investment in children's human capital, such as government provision of education and health care. Solon's model suggests several things: that higher-income parents invest more in their children's human capital, that more progressive public investment in children's human capital partially crowds out parents' investment, and that parents are likely to invest more when the returns to human capital increase. The model predicts that intergenerational mobility will decrease during a period of increasing returns to human capital because rich parents are able to invest more than poor parents, and that mobility will increase during a period of more progressive public investment.

Recent trends in intergenerational mobility do correspond to Solon's predictions (Mazumder 2012). The returns to college education dropped during the 1940s, remained steady for several decades, and then began rising around 1980. These turning points in the returns to college education match the turning points in intergenerational elasticity observed in Aaronson and Mazumder (2008), as well as in other studies of mobility trends.

In Solon's (2004) model, the degree of progressivity of public education is exogenous - that is, determined outside the model. Andrea Ichino, Loukas Karabarbounis, and Enrico Moretti (2011) develop a model in which the degree of progressivity is the outcome of sociopolitical forces. In their model, public education is an insurance system that increases the future income of children without much innate talent at the expense of the future income of children with high innate talent. Public education thus increases mobility. But currently rich dynasties prefer low mobility for their descendants (as will be discussed in more detail in the following section), so in countries where rich dynasties are more politically active, spending on public education will be lower.

\footnotetext{
${ }^{12}$ For a thorough treatment, see Mulligan (1997).
} 
In the United States, spending on public education mostly begins with kindergarten. But children face differences even before they begin school that may determine their future success. Mazumder (2008) finds that educational attainment alone is not enough to explain different mobility rates among black and white children. Black and white people who have completed the same number of years of school still have different intergenerational mobility rates, particularly at the level of high school completion and below. Other research also has found that educational attainment can explain less than half of the intergenerational transmission of earnings (Bowles, Gintis, and Groves 2008).

What this research implies is that human capital embodies more than the number of years spent in school. For example, adolescents who score higher on the Armed Forces Qualifying Test (AFQT) are more likely to move out of the bottom income quintile, and differences in AFQT scores can explain nearly all of the black/white mobility gap (Mazumder 2008). ${ }^{13}$ These test scores, however, capture much more than innate intelligence or academic achievment; non-cognitive skills such as work ethic, the ability to follow instructions, motivation, and patience also are essential to success on such standardized tests (Bowles, Gintis, and Groves 2008; Heckman 2008). In fact, these non-cognitive skills may be just as important as cognitive skills in determining future success in the labor market. For example, the General Educational Development (GED) credential is supposed to demonstrate cognitive equivalence between people who have graduated from high school and people who have dropped out and taken the GED exam instead. But GED holders have much poorer labor market outcomes than high school graduates despite obtaining equivalent knowledge. The reason, James Heckman and other economists have concluded, is that many students who earn a GED lack the non-cognitive skills that would have enabled them to complete high school - the same skills that would help them succeed in the labor market (Heckman, Humphries, and Mader 2010).

Recognizing the importance of non-cognitive skills begs an important question: How do children acquire these skills? A consensus now exists that the foundation is laid very early in life, even from infancy. Skill development is hierarchical; the early mastery of basic emotional, social, and other non-cognitive skills makes it easier to learn more complex cognitive skills throughout life. And children who fall behind early have difficulty catching up. Gaps in cognitive skills that are important

\footnotetext{
13 The AFQT is administered by the military to determine qualification for enlistment. AFQT scores have been widely used by economists as a measure of pre-labor market skills.
} 
for adult outcomes are present as early as age 5 and tend to persist into adulthood (Heckman 2008).

The data suggest that poor and minority children are much more likely to fall behind. A recent report from the Brookings Institution (Sawhill, Winship, and Grannis 2012) examines the likelihood of achieving certain social and economic milestones on the path to the middle class, defined in the report as having a family income at least 300 percent of the poverty level, or about $\$ 70,000$ for a married couple with two children. Only 48 percent of children from families in the bottom income quintile are ready for school at age 5 , compared to 78 percent of children from families in the top quintile. ${ }^{14}$ There also is a large disparity in early childhood outcomes according to race. Sixty-eight percent of white children are ready for school at age 5 , versus only 56 percent of black children and 61 percent of Hispanic children. The gap between white and black widens throughout the lifespan. By age 11, 73 percent of white children versus 52 percent of black children have basic reading and math skills. By age 29 , only 33 percent of black people have successfully transitioned to adulthood (defined by the authors as living independently and having either a college degree or a family income at least 250 percent of the poverty level), while 68 percent of white people reach this milestone. Hispanic people fare somewhat better; 66 percent achieve the age- 11 milestone, and 47 percent reach the age-29 milestone.

\section{CHALLENGES FOR POLICYMAKERS}

What is the role for public policy, if any, in addressing economic inequality and mobility? Answering this question requires asking several others: What would policy try to achieve, and in particular, whose well-being would it attempt to enhance? Would the goal be to improve opportunities for current cohorts or for future generations? Would policy treat individuals at different moments in time as discrete units, irrespective of their ancestors, or would it emphasize dynasties by taking into account how family members invest in descendants?

From a policymaker's point of view, mobility might be inadequate as a measure of what a good society should provide its members. First of all, there is a tradeoff between mobility and predictability. Recall the imaginary world resembling a caste system described earlier. This setting is utterly immobile and risky for each dynasty's first member. But it is perfectly safe for the members of each successive generation

\footnotetext{
14 The authors define "school-ready" as having acceptable pre-reading and math skills and behavior that is generally school-appropriate.
} 
since income is completely stable. In fact, for a person whose ancestor flipped the $\$ 100,000$ coin, this world is not only safe, but also quite comfortable. On the macro level, it is possible that the costs of large fluctuations and risky income patterns outweigh the benefits of high mobility and reduced inequality. Peter Gottschalk and Enrico Spolaore (2002) study a model in which there are large welfare gains from greater mobility if aversion to inequality is the only consideration. But if aversion to income fluctuations is considered, those gains disappear. Of course, this might not be of great consolation to a person whose ancestor flipped the $\$ 1,000$ coin.

In addition, a world in which mobility is high is one where parents are of little consequence, despite their desire or ability to position their children and grandchildren for future success. Few parents would want to live in a world where their investments in their children have no influence beyond their lifetimes. The flip side is that descendants of people who were not altruistic or who made poor decisions would not be as constrained by their ancestors' actions.

Viewed in this light, what most people might agree on is trying to promote individual productivity while limiting downward mobility. Broadly speaking, the former goal involves ensuring preparedness at labor market entry, while the latter involves insuring households against low innate abilities, poor health, or job loss. Knowing the extent to which these forces matter is crucial for policy interventions to be effective. For example, if workers were similarly prepared at the time of entry into the labor market, and shocks in working life were important, the question would be how, if at all, to better insure workers, and not how to alter educational investment decisions. Conversely, if preparedness differed and shocks during working life were unimportant, further insuring workers would yield little benefit. Instead, changes to the educational system would be more effective.

Both factors are important, according to a recent line of work exemplified by Mark Huggett, Gustavo Ventura, and Amir Yaron (2011). They find that about 60 percent of the observed disparity in lifetime earnings is due to individual differences that exist before people enter the labor market, and the remainder is due to shocks that buffet them as they work, such as job losses. Their research stresses that the observed evolution of earnings inequality over lifetimes is consistent with a simple setting in which all workers accumulate skills through experience and effort, but do so at substantially different rates that reflect their initial "learning" ability. At the same time, their estimates clearly indicate that a substantial portion of inequality is generated during working life. This suggests that shocks to earnings are essential to a successful theory of earnings dispersion in the economy. 
A critical point here is that the disparity in learning ability likely arises not only from differences in innate ability, but also from forces such as the quality of K-12 education and parental and cultural influences. These forces are very different for children from poor versus rich families - a dynamic that is magnified by a labor market that demands increasing levels of skill.

\section{INVESTING IN HUMAN CAPITAL}

For most people - all but a lucky few-labor is what they can sell to generate income. They can increase the value of their labor by acquiring greater skills, but the value of their labor is only partially under their control. It also depends on the supply and demand for their skills in the marketplace.

The industrial revolution, for example, created factories that made workers more productive and more valuable without substantially increasing their skills. But the information revolution has created a marketplace that rewards personally acquired skills, such as computer programming or mathematical analysis. In this new environment, an individual's innate ability and early life education become critical because they largely determine the levels of skills each person can develop to "rent" to the marketplace.

Given the large earnings gap between workers with and without college degrees, many policies aim to increase college access, for example by increasing federal subsidies for student loans. But it's not clear that college is the best focus for policymakers. The observed disparity between high school and college graduates applies to students who have graduated from college already; those students who have not yet enrolled might not necessarily receive the same benefit, perhaps because they are not as well prepared. For example, Lutz Hendricks and Oksana Leukhina (2012) find in preliminary work that about 70 percent of the lifetime earnings gap between high school and college graduates results from ability selection rather than from attaining the college degree per se. In other words, the college graduates were likely to be better earners even before entering college.

Intervening well before college could yield much higher returns. As noted above, the skills learned early in life prepare children to obtain more complex skills later in life. Heckman and many other researchers have found that the return on a dollar invested in human capital is highest when the investment occurs at age 3, and that children who receive high quality early education fare much better on a variety of socioeconomic measures (Heckman 2008). 
The most cost-effective policy for increasing equality of opportunity is thus likely to be one that shifts funding away from universal college subsidies and toward early childhood interventions. Elizabeth Caucutt and Krishna Kumar (2003) find that a large increase in college subsidies with the goal of reducing the "enrollment gap" leads to very inefficient use of education resources, with little or no welfare gain, because more poorly prepared students enroll and the dropout rate increases. In a model of human capital transmission in which parents invest in their children, Diego Restuccia and Carlos Urrutia (2004) find that subsidies for investment in early education are much more effective at mitigating persistence in earnings than subsidies for college.

Investments in early childhood education can be viewed as a form of insurance against the risk of being born to poor parents, among other things. And while the public provision of such insurance could yield a big "bang for the buck" by enabling current generations to invest more in the education of future generations, one must also acknowledge the potential for moral hazard. A public system that equalizes the educational opportunities (or far more ambitiously, the home environments) of poor and rich children could reduce the incentives of all parents to invest in children. ${ }^{15}$

Greater public investment in early childhood education cannot replace the advantages that some parents are able to bestow upon their children, nor can it guarantee that all children will grow up to be prosperous. But such investments could give more children the necessary foundation for future acquisition of skills, and ensure that large amounts of human capital are not foregone simply because many children are born to poor families. This foregone human capital is a loss not only for the child, but also for society as a whole. According to an influential line of research, long-run economic growth depends on the amount of human capital in a society. ${ }^{16}$ Unlike physical capital, which exhibits decreasing returns to scale, human capital might well exhibit increasing returns. Knowledge leads to new ideas and new technologies, which lead to higher productivity, thus raising per capita income and living standards for society as a whole.

As this essay has discussed, economic inequality has increased significantly in the United States in recent years. At the same time, data suggest that economic mobility also has decreased, particularly for those born at the top and the bottom of the income distribution.

\footnotetext{
15 See Chang and Kim (2012) and Seshadri and Yuki (2004) for more on the "price of egalitarianism."

${ }^{16}$ Influential papers on "endogenous growth theory" include Romer (1986) and Lucas (1988).
} 
Many factors contribute to the attainment and persistence of economic status, including innate ability, preferences for present versus future rewards, aversion to risk, and quite a bit of luck. But for nearly all people, advancement depends critically on opportunities to obtain human capital - and those opportunities are not the same for children born to poor versus rich families. Policies that aim to equalize these opportunities, particularly very early in life, appear to yield a very high return on investment, although much remains to be learned about the feasibility of implementing such interventions on a large scale. Nonetheless, such efforts have the potential to help the United States achieve a more inclusive prosperity.

\section{APPENDIX}

The following section appeared as a sidebar in the original article.

\section{THE ROLE OF CHOICE}

Inequality and immobility partially reflect deliberate choices related to the fact that people differ in their tolerance for risk or in their willingness to defer gratification (what economists call "time discounting"). But these differences cannot be directly observed. Instead, economists must make inferences based on actual outcomes, such as occupational choice, savings, and consumption.

Risk tolerance has a large impact on occupational choice, and thus on income and wealth. Beginning with Frank Knight's Risk, Uncertainty, and Profit (1921) and continuing in modern work since Richard Kihlstrom and Jean-Jacques Laffont (1979), economists have modeled entrepreneurs as less risk averse than other people and therefore more likely to undertake high-risk/high-return enterprises. To the extent that people genuinely vary in risk aversion, this model suggests that the rich and the poor disproportionately will be those with high risk tolerance, while those in the middle will be more risk averse. This is consistent with data that show a disproportionate number of selfemployed people at both ends of the earnings and wealth spectrums. They also figure more prominently among households in financial distress (Sullivan, Warren, and Westbrook 2000).

Additional evidence for the role of risk tolerance in personal economic outcomes comes from Sam Schulhofer-Wohl (2011), who finds that risk-tolerant workers tend to have jobs more exposed to 
economy-wide or "aggregate" risk. Movements in these workers' incomes thus tend to be more volatile even when they have insured themselves against individual-level, or "idiosyncratic," risks, such as job loss or illness. As a result, volatility in their consumption of goods and services is not necessarily evidence of poor insurance possibilities in the marketplace. Indeed, Schulhofer-Wohl (2012) finds that after correcting for this bias, U.S. households do not appear to be bearing any significant uninsurable risk. (A variety of other research, however, has found that certain types of shocks, such as a long-term disability, are clearly not fully insured.)

Observed inequality also might reflect different preferences for consumption in the present versus the future. Per Krusell and Anthony Smith (1998) show, for example, that a model that includes variation in "impatience," or the willingness of households to borrow against future earnings, successfully matches observed wealth inequality in the U.S. population. Emily Lawrance (1991) and Marco Cagetti (2003) also find that data on consumption and wealth suggest the presence of significant differences in preferences, especially in risk-aversion and time discounting. They find that less-skilled and less-wealthy individuals generally are less patient-meaning they place a higher value on current versus future consumption - than their more-skilled and wealthier counterparts. More recently, Lutz Hendricks (2007) has measured the extent of differences in households' discount factor by noticing that households vary a great deal in their wealth even though they have and can expect to have very similar lifetime incomes.

Taken as a whole, economists' work suggests that many of the observed differences in the way households make decisions can be understood as arising from differences in risk tolerance or time discounting. A caveat, however, is that a variety of difficult-to-model environmental forces might play a large role in generating these differences. In a society with low life expectancy or a high violent crime rate, for example, individuals might not be "choosing" to be impatient so much as making a rational decision to value current over future consumption. Likewise, not attending college might indicate an individual with a high discount factor who chose not to invest in K-12 education - or it might indicate a person facing strong institutional barriers to attending college. It is important to keep such environmental factors in mind when interpreting any model that includes heterogeneity in preferences. 


\section{REFERENCES}

Aaronson, Daniel, and Bhashkar Mazumder. Winter 2008.

"Intergenerational Economic Mobility in the United States, 1940 to 2000." Journal of Human Resources 43 (1): 139-72.

Aguiar, Mark A., and Mark Bils. February 2011. "Has Consumption Inequality Mirrored Income Inequality?" National Bureau of Economic Research Working Paper No. 16807.

Auten, Gerald, Geoffrey Gee, and Nicholas Turner. January 4, 2013. "Income Inequality, Mobility and Turnover at the Top in the United States, 1987-2010." Paper presented at the Allied Social Science Associations Annual Meeting, San Diego.

Becker, Gary S., and Nigel Tomes. July 1986. "Human Capital and the Rise and Fall of Families." Journal of Labor Economics 4 (3) Part 2: S1-39.

Borjas, George J. Fall 2006. "Making It in America: Social Mobility in the Immigrant Population." Future of Children 16 (2): 55-71.

Bowles, Samuel, Herbert Gintis, and Melissa Osborne Groves. 2008. "Intergenerational Inequality Matters." In Unequal Chances, edited by Samuel Bowles, Herbert Gintis and Melissa Osborne Groves, 1-22. Princeton, N.J.: Princeton University Press.

Cagetti, Marco. July 2003. "Wealth Accumulation Over the Life Cycle and Precautionary Savings." Journal of Business and Economic Statistics 21 (3): 339-53.

Caucutt, Elizabeth M., and Krishna B. Kumar. 2003. "Higher Education Subsidies and Heterogeneity: A Dynamic Analysis." Journal of Economic Dynamics and Control 27: 1,459-502.

Chang, Yongsung, and Sun-Bin Kim. January 2012. "The Price of Egalitarianism." B.E. Journal of Macroeconomics 11 (1).

Congressional Budget Office. July 2012. "The Distribution of Household Income and Federal Taxes, 2008 and 2009."

Congressional Budget Office. October 2011. "Trends in the Distribution of Household Income Between 1979 and 2007."

Corak, Miles. 2006. "Do Poor Children Become Poor Adults? Lessons from a Cross-Country Comparison of Generational Earnings Mobility." In Research on Economic Inequality, Vol. 13, edited by John Creedy and Guyonne Kalb, 143-88. Bingley, U.K.: Emerald Group Publishing. 
K. Athreya and J. Romero: Economic Mobility in the U.S.

Easterlin, Richard A. Winter 2000. "The Worldwide Standard of Living since 1800." Journal of Economic Perspectives 14 (1): 7-26.

Gottschalk, Peter, and Enrico Spolaore. 2002. "On the Evaluation of Economic Mobility." Review of Economic Studies 69 (1): 191-208.

Haskins, Ron. 2008. "Immigration: Wages, Education, and Mobility." In Getting Ahead or Losing Ground: Economic Mobility in America, edited by Julia B. Isaacs, Isabel V. Sawhill, and Ron Haskins, 81-90. Washington, D.C.: The Pew Charitable Trusts.

Heckman, James J. July 2008. "Schools, Skills, and Synapses." Economic Inquiry 46 (3): 289-324.

Heckman, James J., Lance J. Lochner, and Petra E. Todd. February 2008. "Earnings Functions and Rates of Return." National Bureau of Economic Research Working Paper No. 13780.

Heckman, James J., John Eric Humphries, and Nicholas S. Mader. June 2010. "The GED." National Bureau of Economic Research Working Paper No. 16064.

Hendricks, Lutz. September 2007. "How Important Is Discount Rate Heterogeneity for Wealth Inequality?" Journal of Economic Dynamics \& Control 31(9): 3,042-68.

Hendricks, Lutz, and Oksana Leukhina. May 2012. "The Return to College: Selection Bias and Dropout Risk." Manuscript, University of North Carolina, Chapel Hill, and University of Washington.

Huggett, Mark, Gustavo Ventura, and Amir Yaron. December 2011. "Sources of Lifetime Inequality." American Economic Review 101 (7): $2,923-54$.

Ichino, Andrea, Loukas Karabarbounis, and Enrico Moretti. January 2011. "The Political Economy of Intergenerational Income Mobility." Economic Inquiry 49 (1): 47-69.

Isaacs, Julia B. 2008. "Economic Mobility of Black and White Families." In Getting Ahead or Losing Ground: Economic Mobility in America, edited by Julia B. Isaacs, Isabel V. Sawhill and Ron Haskins, 71-80. Washington, D.C.: The Pew Charitable Trusts.

Kihlstrom, Richard E., and Jean-Jacques Laffont. August 1979. "A General Equilibrium Entrpreneurial Theory of Firm Formation Based on Risk Aversion." Journal of Political Economy 87 (4): 719-48.

Knight, Frank H. 1921. Risk, Uncertainty, and Profit. Hart, Schaffner, and Marx Prize Essays, no. 31. Boston: Houghton Mifflin. 
Kopczuk, Wojciech, Emmanuel Saez, and Jae Song. February 2010.

"Earnings Inequality and Mobility in the United States: Evidence from Social Security Data since 1937." Quarterly Journal of Economics 125 (1): 91-128.

Krusell, Per, and Anthony A. Smith, Jr. October 1998. "Income and Wealth Heterogeneity in the Macroeconomy." Journal of Political Economy 106 (5): 867-96.

Lawrance, Emily C. February 1991. "Poverty and the Rate of Time Preference: Evidence from Panel Data." Journal of Political Economy 99 (1): 54-77.

Lubotsky, Darren H. October 2007. "Chutes or Ladders? A Longitudinal Analysis of Immigrant Earnings." Journal of Political Economy 115 (5): 820-67.

Lucas, Robert E. Jr. July 1988. "On the Mechanics of Economic Development." Journal of Monetary Economics 22 (1): 3-42.

Mazumder, Bhashkar. May 2008. "Upward Intergenerational Economic Mobility in the United States." Economic Mobility Project, The Pew Charitable Trusts.

Mazumder, Bhashkar. April 2012. "Is Intergenerational Mobility Lower Now than in the Past?" Federal Reserve Bank of Chicago Chicago Fed Letter, no. 297.

Meyer, Bruce D., and James X. Sullivan. January 4, 2013. "Consumption and Income Inequality in the U.S. since the 1960s." Paper presented at the Allied Social Science Associations Annual Meeting, San Diego.

Mulligan, Casey B. 1997. Parental Priorities and Economic Inequality. Chicago: University of Chicago Press.

Passel, Jeffrey, D’Vera Cohn, and Ana Gonzalez-Barrera. April 2012. "Net Migration from Mexico Falls to Zero - and Perhaps Less." Pew Research Hispanic Center.

Piketty, Thomas, and Emmanuel Saez. February 2003. "Income Inequality in the United States, 1913-1998." Quarterly Journal of Economics 118 (1): 1-39.

Pritchett, Lant. 2006. Let Their People Come: Breaking the Gridlock on Global Labor Mobility. Washington, D.C.: Center for Global Development.

Restuccia, Diego, and Carlos Urrutia. December 2004. "Intergenerational Persistence of Earnings: The Role of Early and College Education." American Economic Review 94 (5): 1,354-78. 
K. Athreya and J. Romero: Economic Mobility in the U.S.

Romer, Paul M. October 1986. "Increasing Returns and Long-Run Growth." Journal of Political Economy 94 (5): 1,002-37.

Saez, Emmanuel. January 2013. "Striking It Richer: The Evolution of Top Incomes in the United States (Updated with 2011 Estimates)." Manuscript.

Sawhill, Isabel V., Scott Winship, and Kerry Searle Grannis. September 2012. "Pathways to the Middle Class: Balancing Personal and Public Responsibilities." Brookings Institution Center on Children and Families.

Schulhofer-Wohl, Sam. October 2011. "Heterogeneity and Tests of Risk Sharing." Journal of Political Economy 119 (5): 925-58.

Seshadri, Ananth, and Kazuhiro Yuki. October 2004. "Equity and Efficiency Effects of Redistributive Policies." Journal of Monetary Economics 51 (7): 1,415-47.

Shorrocks, Anthony. December 1978. "Income Inequality and Income Mobility." Journal of Economic Theory 19 (2): 376-93.

Solon, Gary. 2004. "A Model of Intergenerational Mobility Variation over Time and Place." In Generational Income Mobility in North American and Europe, edited by Miles Corak, 38-47. Cambridge, England: Cambridge University Press.

Stokey, Nancy L. 1996. "Shirtsleeves to Shirtsleeves: The Economics of Social Mobility." In Frontiers of Research in Economic Theory: The Nancy L. Schwartz Memorial Lectures, 1983-1997, edited by Donald P. Jacobs, Ehud Kalai and Morton I. Kamien, 210-41. Cambridge, England: Cambridge University Press.

Sullivan, Teresa A., Elizabeth Warren, and Jay Lawrence Westbrook. 2000. The Fragile Middle Class: Americans in Debt. New Haven and London: Yale University Press. 